\title{
"Your Majesty, your son is unable to learn?": A Study of the Notions of 'Learning' and 'Teaching' Inscribed in a Sample of Southern Folk Tales from Ancient Lanka
}

\section{Lal Medawattegedara*}

Department of Language Studies, The Open University of Sri Lanka, Sri Lanka

\section{Abstract}

Despite textual and other historical evidence pertaining to 'learning' and 'teaching' in ancient Lanka is sparse scholars have focused their attention on such notions. However, there is rich evidence for 'learning' and 'teaching' in ancient Lanka's folktales which treat these concepts as 'lived experiences' of protagonists occupying imaginary worlds. Yet, there has been minimal scholarly attention paid to folktales. This paper focuses on those folktales with the objective of locating what such storytelling tells us about the way common folks perceived education. Using a folkloristic standpoint which views folk speech acts as being carriers of not only cultural embellishments but cultural predispositions, this study attempts to locate what the notions of 'learning' and 'teaching' present in stories told by southern Lankans tell us about their deepseated attitudes to/understandings of education. The study uses Henry Parker's Ceylonese folktales as its sample and attempts to locate the enabling conditions that uphold the ideas of 'learning' and 'teaching' to achieve its objectives.

Key words: Learning, Teaching, Folktales, Story-telling, Attitudes

\footnotetext{
* Corresponding should be addressed to Mr. Lal Medawattegedara, Department of Language Studies, The Open University of Sri Lanka, Sri Lanka.
}

Email: lalmedawattegedara@gmail.com

(D) https://orcid.org/0000-0003-3351-1889

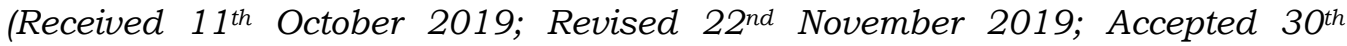
November 2019) (C) OUSL) 


\section{Introduction}

Though folkloric speech acts-folktales, folksongs, folk drama, myths and etc.- - are largely told/heard/read for purposes of entertainment by ordinary 'folk' and might not readily invite in-depth scholarly attention, such narratives are not culturally unembellished and neutral. Folktales, the focus of this study, are not created in a vacuum and they reflect the socio-cultural conditions of their time of creation/narration and transmit them across time and space often, as a folklorist suggests, "unconsciously or selfunconsciously" (Dundes 1980). Take the case of Sinhala folktales: they disseminate "common cultural traditions" (Weeresekera 1997) and offer "subtle resistance" (Weeresekera 1997) to those in power-he does not elaborate on this important idea of resistance. Gencarella (2010), on the other hand, aligns folktales with those in power when he argues that people who are exposed to the traditional, insular worldviews disseminated by folklore would not be capable of organizing themselves politically. Roberts (2003) implicitly agrees with Gencarella given that his extensive study of oral modes of communication in the Kandyan period (1590-1815) views orally transmitted speech as participating in the "organization of life" and the "exercise of power" by the Kings in the historical period under focus (Roberts 2003). The point this writer wishes to make here is that folk narratives tend to be 'political' as well as 'cultural' and therefore, merit more serious attention from scholars.

The syllabus designers of the modern Lankan state have opted to include samples of folklore in the school syllabuses, possibly with the understanding that the narratives are purveyors of (positive attributes) of culture ${ }^{1}$. Yet, folkloric narratives need not always be acceptable discourses for the culturally conservative masses in a social setting. Folklore also conveys "biases and prejudices" (Dundes, 2010) and one specific group that has been the target of such disparagement in the USA is teachers, according to Dundes (2010). Despite the brevity of his original discussion on this subject, he argues that American folklore disseminate "resentment" (Dundes, 2010) towards teachers and educational administrators. The present research too focuses on related motifs: 'learning' and 'teaching.' This paper attempts to undertake a close reading of a sample of southern Lankan folktales collected by a

\footnotetext{
${ }^{1}$ School curriculum for the Sinhala/English languages features folktales and folksongs
} 
British colonial officer, Henry Parker, during the late 19th century to understand how 'learning' and 'teaching' may have been conceived by a community of rural Sinhala speakers in Ceylon's South. Parker collected these tales from native Sinhala speakers of the South while he was engaged in irrigation work for the (British) colonial government. Through a close reading of Parker's 266 tales, with the primary focus on the acts of 'learning' and 'teaching', this study attempts to understand how pedagogy and its (supposed) end product, erudition, could have been perceived by the 'folk' who either created/narrated/heard the fictional universes and plots in those tales to entertain themselves at intimate family gatherings, as noted by the British colonial official in Sri Lanka, John Davy (1983).

Parker's 266-tale compilation is Lanka's first major folktale collection published in any language. Those tales are largely devoid of Buddhist influences ${ }^{2}$ and neither do they feature as cultural influences, let alone characters, of the European colonizers - the Portuguese, Dutch and British-whose presence has inevitably found its way into Lanka's mainstream and folk culture. ${ }^{3}$ Parker's tales largely feature fictional universes peopled by humans, anthropomorphic animals, and supernatural beings amidst social spaces shaped by caste, class, the paranormal and the patriarchal. Folklorist Crooke, who was one of the first scholars to review Parker's folktales, asserts that these folktales are essentially pre-Buddhist. ${ }^{4}$ His argument is based on the absence of European colonial influence as well as Buddhist influences in the tales. At the same time, another aspect of the tales that had escaped the attention of Crooke-and Parker's 5 -is the absence of local regional deities in the folktales. Ancient-and modern-Lanka is home to cults

\footnotetext{
${ }^{2}$ Three tales of Henry Parker feature Buddhist monks as characters. Buddhist ideas or morals are largely absent from the tales.

${ }^{3}$ There are Sinhala folktales that feature the European invaders to Lanka. One specific example is: Parangi Rajjuruwo Saha Thawath Katha (The Portuguese King and Other Tales) by

Mahanama Dunuwala. See References.

${ }^{4}$ It is generally accepted that Buddhism was introduced to ancient Lanka approximately in 300 BCE by Arahant Mahinda who headed a team of Buddhist missionaries from neighboring India. There are scholarly disagreements on the dates and the mode of introduction of the religion and such arguments are beyond the scope of this paper.

${ }^{5}$ Parker wrote an extensive Introduction to the folktales to familiarize the reader with the context that gave him the tales as well as to inform the reader of his mode of collection, compilation and translation of the tales
} 
formed around regional deities of native and non-native origin with many folktales/poems/rituals woven around them. The deities found in Parker's folktales-identified as devata-are generic, in the sense that they lack the idiosyncrasy and individuality granted to local regional gods by their believers through creation myths, birth stories and specific attributes of power. One way of reading the absences of Buddhist influences, European colonizers, and local regional gods in Parker's folktales is that the tales he collected could be some of the oldest in the country. Their remoteness from the centers of power-Parker himself asserts that he had collected the tales from rural areas and taken specific care to ensure that the tales were devoid of what he called "European influences" (Parker 1910)—might have made them impervious to mainstream cultural influences. This particular reading of Parker's tales as some of the oldest in Lanka informs this paper as it seeks to explore how common people of Lanka perceived 'learning' and 'teaching' in the fictional sphere and what such perceptions could tell us about 'learning' and 'teaching' in the material sphere.

\section{Review of Literature}

It would be pertinent at this point to understand how 'learning' and 'teaching' were understood in ancient Lanka in discourses other than folklore, though that knowledge might not have significant impact on the present study. Though historicity of education in ancient Lanka could offer a reader a representation of a (near) 'authentic' state of 'learning' and 'teaching' that existed in ancient Lanka-one could always argue against the 'authenticity' of the original sources from which such information is extracted. Folktales, on the other hand, are imaginative texts, and need not necessarily capture a 'presence' of the modes of teaching-learning prevalent at the time of their creation/telling/hearing. Yet, folkloric texts, as Gancerella (2010) argued, record and preserve the 'modes of thinking' associated with previous hegemonies. The objective of this paper is to locate and analyze these modes of 'thinking' specifically related to 'learning' and 'teaching' in ancient Lanka as they are preserved in a sample of folktales. This study therefore does not undertake to offer an 'authentic' state of education in ancient Lanka. Rather it offers a way a way of exploring how such notions might have been conceived by the people who created/believed in and subscribed to the tales under focus. Thus, what follows is a summary of the available scholarship on ancient Lanka's education.

Education in pre-Buddhist Lanka, according to the scholar Jayasuriya 
(2018), was a two-tiered system: apprenticeships for 'commoners' (he does not offer detailed information of this category) and a system of schooling for the royal class. "The kings or chieftains had Brahamin teachers" (Jayasuriya 2018) and "(t)he craftsmen needed for the economy were turned out through apprenticeship..." (Jayasuriya 2018). Suraweera (2008) also echoes this notion in his work which uses Lanka's ancient chronicles as sources to suggests that tutors of royal princes were Brahamins. Both these scholars surmise that education became the prerogative of the Sangha after the advent of Buddhism in Lanka with the Buddhist monk becoming the teacher and the temple being the site of education. Jayasuriya (2018) claims that this system, where religious edification became the priority, did not ignore "secular subjects" (Jayasuriya 2018) even though he does not identify these subjects nor does he elaborate. Furthermore, Suraweera argues that the Sangha-driven education process also involved ordinary masses because the monks also preached the finer points of religion to ordinary people. Folklorist Ratnapala (1991) adds an interesting point to this view when he argues that the basic tenants of Buddhism were disseminated among the laity using the Jataka Tales, ${ }^{6}$ which were imported from ancient India. Erudition in ancient Lanka was identified not as being "well-read" but as "those who have heard a great deal" (Jayasuriya 2018); thus "committing knowledge to memory" (Suraweera 2008) was the mode of learning in ancient Lanka. Coomarsawamy (2003) commenting on education in Lanka during a much later age-Kandyan period (1590$1815)$-notes that children were initiated to education at the age of six (06) and they began with writing. Yet, Suraweera (2008) quoting ancient texts, suggests that the age of initiation of a child to education was 12 years in the Polonnaruwa and Dambadeni periods. Though he does not commit to a time period, Jayasuriya (2018) lists the following classification criteria as "an early attempt" (Jayasuriya 2018) at an analysis of the learning process in ancient Lanka: acquisition of knowledge, comprehension, retention and disseminate knowledge to others. Despite the thinness of information in scholarship quoted above, it is possible to understand that 'education' in ancient Lanka as an idea motivated by social class/caste and Buddhist spirituality-in other words 'education' was not a singular notion acceptable to all, rather it

\footnotetext{
${ }^{6}$ Buddhist Jataka Tales are considered "the most reliable, the most complete and the most ancient collection of folklore now extant in any literature in the world" (Davids 1987) - see reference for full citation
} 
was a notion that played into/upheld the social conditions of the day and could have been regulated by those selfsame social values. Folktale had a presence in this system of education as a tool of teaching-but they were for the masses and not the elite. So, how did the common masses - the ones who listened to Jataka Tales preached by early Buddhist monks-perceive 'learning' and 'teaching'? Like the historian John Man, who turns to folklore when historical sources into the life of Genghis Khan runs into a vacuum, ${ }^{7}$ this paper too would resort to Parker's folktales to understand the possible perceptions of common folk towards 'learning' and 'teaching.'

Though Parker's collection of folktales is not without certain scholarly issues-such as his translation of the tales from Sinhala into English, his own colonial (British) subjectivity-such issues are beyond the scope of this paper. Despite those short comings, Parker has left a large collection of folktales for posterity, and his tales are still in circulation in the modern nation state either as translations or retellings. It would be of interest to isolate, examine and understand how the notions of 'learning' and 'teaching' could have been understood by southern folk in the imaginative tales they recited/created/heard for entertainment. How did the common people of ancient Lanka view the ideas of 'learning' and 'teaching'? How did a 'teacher' view the act of 'teaching'? How did 'learning' and 'teaching' play into the lives of ordinary people? This paper attempts to answer these questions for purposes of cultural comprehension by undertaking a close reading of the tales.

This research will isolate the acts and motifs related to 'learning' and 'teaching' to understand the conditions that uphold their existence. All speech, according to Macherey "envelopes in the unspoken in order to reach utterance" (Macherey 1993), and this "silence" (Macherey 1993), informs us of the "precise conditions for the appearance of a tterance,

7 "In 1227 this valley might have been a huge glade of crops and pastures, a perfectly wonderful base to hide a nomadic army. I needed something to make sense of all this. Maybe folklore would help. Perhaps, there would be old people to talk to." (Genghis Khan —Life, Death and Resurrection, John Man) 
its limits...real significance" (Macherey 1993). These silences that surrounds the ideas of 'learning' and 'teaching' of the tales will be put under scrutiny in this study to understand how common folks in Southern Lanka of an unspecified time period could have viewed education.

\section{Findings and Discussion}

The notions of 'learning' and 'teaching' as conceived by the story tellers/creators/listeners of ancient Lanka is presented under different thematics as follows:

\section{'Learning'}

\section{a) Only the privileged class/caste/gender were exposed to 'learning'}

'Learning' in Parker's folktales is a privilege built around male characters from the royal class with an occasional royal female thrown in-males 'go to school,' 'learn,' 'read' and 'write'. At the same time, notions of 'learning' are only present in the tales narrated by the cultivating castewhose tales make up the majority in Parker's collection ${ }^{8}$ and such ideas do not appear in the tales he collected from the 'lower' castes ${ }^{9}$. Thus, only royal princes learned 'the sciences,' to quote a Brahamin father from one of Parker's tales. By constructing 'learning' around privileged class/caste/gender the storytellers could have been attempting to justify the assumed 'pre-eminence' and even 'dominance' of a specific group of people over others and thus sustaining a preferred social hierarchy. This substantiates Gencarella's (2010) theoretical assumption of folklore being a preserver of past hegemonies. But, inscribed in the tales Parker collected from Ceylon's lower castes were traces of resistance offered by them to the higher castes where they ridiculed the high caste people by

8 Of the 266 tales of Parker, 210 were ascribed to raconteurs from the cultivating caste, the rest to the lower castes

${ }^{9}$ In ancient Lanka's casteism, the cultivators (govi) were considered the highest caste next to the rulers (raja) 
positioning them in their tales as dim-witted characters. Yet, why did those radical tales from the oppressed castes leave out the idea of 'learning' from their tales? ${ }^{10}$ After all, learning, as mentioned above, was associated with power in the tales of the higher castes. However, silences in texts are not to be overlooked. "To speak is to be known," argues Wickramagamage (2009), because it "enables the knower to claim possession"; yet, "to refuse speech...is to remain outside the orbits of representation and, by extension, to refuse appropriation by the knower." The presumed 'silence' of the low-caste story creator/teller with respect to education could be because they perceived no value in the notion of formal 'learning.' In a society where one could easily learn their caste-based profession (eg. drumming, washing) at home lofty ideals of formal education could have been deemed impractical and redundant exercises. Yet, Suraweera (2008) offers an interesting argument about literacy in ancient Lanka: the presence of a large number of stone inscriptions in the nation, some of the oldest going back to the $3^{\text {rd }}$ Century BCE, indicates a high rate of literacy among people. In other words, he insinuates that most people of ancient Lanka, regardless of their class/caste, knew how to read a text. If that is the case, then one could assume that ancient Lanka's citizens were offered some kind of formal learning in the residence of a teacher or elsewhere making 'learning' an inevitable fact of life. Thus, for those from the oppressed castes, whose social mobility was thwarted by social conditions, learning only served a practical purpose (eg. reading an important inscription) whereas for the privileged castes, learning was a critical, social act in addition to its practical purposes. For the lower castes, learning was an option, something that they could achieve at their own pace and time'learning' did not govern their lives. Therefore, there was no need for their tales to offer undue significance to this act. The other question one could also ask is the reasons for the obvious gender bias towards males with respect to 'learning'. Parker's tales are products of a deeply patriarchal social setting ${ }^{11}$ and these tales could have played a critical role in preserving the sites of power in those settings for males of the high caste/class. Thus, 'learning' was a motif that acted as a deterrent to females from pursuing formal education or being empowered, and by

\footnotetext{
${ }^{10}$ This will be further discussed in the author's forthcoming paper: Casteism in Henry Parker's Village Folk Tales

${ }^{11}$ See Medawattegedara (2015): “We Must Make Men”: Construction of Masculinities and

Femininities in Parker's Village Folk Tales of Ceylon. OUSL Journal, Volume 9, 2015.
} 
extension, occupying seats of power. Either way, the notion of 'learning' was a problematic event for Lanka's story tellers, functioning as a sluice gate at a water reservoir-it appears to have been opened for some and closed for others.

\section{b) Learning happens in a specific space}

Ceylonese folktales situate learning in a generic space (identified as 'school' though one need not imagine a 'school' in the modern sense)and in one story this space is identified as the personal residence of a teacher ${ }^{12}$. Students are frequently found 'going to school' in the morning. Take the tale The Prince Who Did Not Go to School. Here two princes "go to school," (Parker1910) every morning, and as the title suggests, one deliberately avoids school. In the tale, The Prince who Received the Turtle Shell, a young prince is "sent to a teacher to learn," (Parker1910) suggesting the teacher's residence as a separate space for learning. In The Story of the Cobra's Bite, a prince is "handed over" (Parker 2010) to the "Royal Preceptor" (Parker1910) to be educated. The implications are that the southern story tellers/creators/listeners imagined 'learning' as an activity that takes place-or should take place-in a separate space, managed by an educator where a student is required to be present. This location of the process of teaching/learning in a separate space implies that common people were familiar with 'learning' as a process that requires the removal of a learner from his/her familiar environs. At the same time, since Parker's tales only use the notion of 'learning' for the ruling class, a separate space for learning/teaching could have facilitated the act of learning by removing young princes from their immediate spheres of influence and power. At the same time, this space might have promoted the socializing of the young ruling elite with others of their class.

\section{c) Learning and Punishment}

Ceylonese folktales tales frequently promote the idea of harsh punishments for those who do not make the best of opportunities to learn. Thus, in the tale Concerning the Prince and the Princess who was Sold, a prince deliberately neglects his learning and is discovered when

\footnotetext{
12 Studying at the teacher's residence is a well-known idea among the Buddhists: Prince Sidhartha, the founder of the religion, was educated at his teacher's residence.
} 
he is unable to read a letter at the request of his father, the king. The angry king immediately orders the beheading of his son. In the tale The Prince who Received the Turtle Shell, a prince who is not skilled in learning becomes the subject of humorous banter by the other princes. Unable to withstand these veiled insults, the victim leaves the palace. One could assume from the tales that for males of the royal class, learning was compulsory; their parents were observant of their educational progress-and they expected success. The presence of notions such as 'observing and assessing learners,' and 'punishing those who failed to learn' in the tales related to the royal princes (and few princesses) narrated by the high castes suggests that the Lankan story tellers/creators/listeners considered learning as a critical aspect for rulers and of ruling. The analysis of the functioning of a ruler in the tales also plays into this idea: rulers are frequently depicted settling legal disputes, intervening to settle serious social issues among their subjects, listening to poetry, appreciating aesthetic products and even conversing with highly intelligent persons. Thus, erudition was a common expectation of rulers.

In addition to harsh punishments, Lankan story creators/tellers also linked 'learning' to the institution of marriage-finding a suitable bride was predicated on 'learning.' Take the case of The Nobleman and His Five Sons. A royal wife chases her husband, a son of a nobleman, because he lacked education. "What do you know of the Sciences?" (Parker, 1910) she asks him, and he responds: "I don't know a single one" (Parker, 1910). She drives him away saying, "If so, you cannot stay near me; go away" (Parker, 1910). When the humiliated young man goes home, his father takes the issue seriously and sends all his sons to learn 'the sciences' with the threat of expulsion from home if they did not succeed. A father rejects four marriage proposals for his daughter sent by four Brahmin youth who have not been exposed to learning in the tale The Attempt of Four Brahmana Princes to Marry. The opposite happens in the tale The Wicked Princess, where a prince who excels in learning is given the teacher's daughter in marriage. Thus, 'learning' and marrying were linked. The 'untaught' men were treated with derision by (ironically) the females who had no or minimum access to learning. In a social setting driven by deep-seated male bias facing and absorbing such serious insults from females might have been considered as an act of emasculation for males-warning enough, we presume, for a high caste/class male to take his education seriously. 


\section{d) Females who learned?}

The stories so far only related how males of the royal class 'learned.' The presence of females who are exposed to 'learning' is sparse, though that notion is not completely absent. The king in the tale, Holman Pissa educates his attractive daughter. Her education stands her in good stead when she is called upon to preside over legal disputes-yet she appears in this role only in male disguise. The subtext of the tale underscores that learning is a useful tool for one's life ${ }^{13}$. In the tale The Prince and the Princess and Two Devatawas one has reason to believe that the female protagonist, a royal princess, is learned since she (in male disguise) is hired by the king as a teacher (all teachers in Parker's tales are erudite males) and an examiner of shipping cargo. This tale does not elaborate on the nature of her duties in the harbour, thus we cannot comment on its potential implications. Yet, these few tales with educated females do not support the gender neutralization of learning, rather they promote the masculine bias in education. The tales seem to say that: someone who is considered knowledgeable and learned in the public sphere is always a 'male' of the royal class. Parker's tales explicitly deny females many social initiatives, and education is only one of them ${ }^{14}$.

\section{e) What they 'learned'}

Some of Parker's folktales pay attention to the subjects learned by their protagonists. In the tale The Princess who Learnt the Sciences, four princes who were unsuccessful in learning and expelled by their father learn the following skills: "soothsaying, theft, archery and carpentry" (Parker 1910). These skills are eventually demonstrated to the king as proof of their learning. In The Nobleman and His Five Sons, five young men learn "soothsaying, theft, making rapid journeys, bringing dead to life and shooting accurately (Parker 1910)." Similarly, in The Seven Princess, seven princes who run away from their palace learn the following skills: "soothsaying, crow's language, shooting, carpentry, ballplaying and thieving" (Parker 1910). In The Attempt of Four Brahmana

\footnotetext{
${ }^{13}$ This reminds one of the Sinhala adage, Ugatha mana shilpaya mai mathu rekena, or it is one's erudition that could save one

${ }^{14}$ For a detailed discussion of gender imbalances in Parker's folktales see Medawattegedara (2015): “We Must Make Men": Construction of Masculinities and Femininities in Parker's Village Folk Tales of Ceylon. OUSL Journal, Volume 9, 2015.
} 
Princes to Marry, the four young men become experts at: "reading omens; travelling through the sky; abating poison; giving new life to a dead person" (Parker 1910). In the tale The Boy Who Went to Learn the Sciences a boy is requested to learn 'the sciences' by his father - with the most significant and important science being the shrewd tactics (mayam) of females. As 'strange' and 'removed from life' as these subjects sound, they become relevant and useful in the universe of the folktales.

The subjects that were learned by these royal elite could be categorized as follows:
a) Military:
shooting, archery
b) Medicine:
abating poison
c) Professional:
carpentry
d) Sports:
ball-playing
e) Astrology:
soothsaying
f) Supernatural: bringing dead to life, making rapid journeys ${ }^{15}$, crow's language, reading omens
g) Social skills:
h) Survival:
reading 'mayam' of females ${ }^{16}$
theft 17

Interestingly, the protagonists who were forced to learn the above subjects were pupils who have come out of the formal learning process (learning at a teacher's residence) due to various reasons. In other words the skills listed above were learned outside the formal teaching system. Thus, there is a strong suggestion that there were locations of 'learning' other than the teacher's residence, and that such locations taught skills that could be considered more practical, helpful and feasible for these fictitious (or non-fictitious) characters.

There is also a tendency among story creators/tellers to valorize supernatural skills, possibly owing to their entertaining appeal. At the same time, these stories offered some mode of 'learning' to its high caste/class protagonists even if they were outside the formal learning

\footnotetext{
${ }^{15}$ Ability to travel through air

${ }^{16}$ Sinhala folklore suggests that females possess 64 ploys (mayam) which they could use to deceive males

${ }^{17}$ For some royal protagonists in Parker's tales' theft under specific circumstances is considered natural and is also important as a skill of survival at some critical point in their lives; they do not commit theft as a habit/profession
} 
process, for example, a prince or a Brahmana young male, despite their lack of success in formal education, learnt supernatural skills and sustained their power. Thus, the stories only ended up perpetuating the existing power structures of their immediate social settings. At the same time, one could also interpret these supernatural skills as wishful thinking of the cultivating castes story tellers who were frequently forced to live with threats to their crops from nature and wild animals and fears of mortality posed by disease. Thus, they floated the 'possibility' of the existence of powers that defied nature as a response in their imaginative spheres.

\section{f) Learning to Read and Write}

Those who learned at a teacher's residence were taught reading and writing skills and the story creators/ tellers located them as critically important skills for royal princes/princess. Thus, in the tale Concerning the Prince and the Princess who was Sold, a prince who did not study is discovered by his father through a deliberate act of reading. The king asks him to read a letter, and the boy fails: "...there are a sort of strokes, and strokes, and a sort of drops..." (Parker 1910). The king orders the beheading of the prince. The Prince and the Princess, a young royal couple escapes from a difficult situation by communicating with each other through messages written on an orange. In The Gamarala's Girl, a king writes an enigmatic letter (the story does not offer details) to a female in order to find a pretext to execute her. The female reads the letter accurately and her ability impresses the king so much that he marries her. These tales, on one hand, reiterate that 'reading' and 'writing' are skills that are closely connected to 'power' and the absence of these skills was considered an absence of 'self'-- or death. None of the ordinary characters featured in Parker's tales face a crisis due to their incompetence in reading and writing. On the other hand, the tales serve to keep the lower class/castes in their specified social position by reinforcing the gap between the 'unlearned' ordinary people and the 'learned' royal class. Parker has unconsciously (or consciously?) participated in this power equation himself given that he has collected orally-transformed tales of common folk of Ceylon and translated (or written!) them for the reading pleasure of the educated class. 


\section{'Teaching'}

\section{a) 'Teaching' as a high caste/male prerogative}

Teachers in Parker's Ceylonese folktales are males of the Brahamin caste-this might be an indication of Parker's tales being older because Lanka's $5^{\text {th }}$ century chronicle, The Mahavamsa, also offers the same position to Brahamins. Only two female characters (of the royal class) became teachers and were forced to practice their craft disguised as males. In The Prince and the Princess, the main character, a princess, teaches while disguised as a male. In the tale The Prince and the Princess and Two Devatawas, a royal princess, works as a teacher and an examiner of shipping cargo-in male disguise. In the fictional universe of the Ceylonese Southern folktales the story creators/tellers opted to associate sites of power (kingship, teaching) with the male gender of the high castes. One could assume that the affairs in the material sphere were no different and even if things were different, these stories could have acted as a psychological barrier for people who did not meet these criteria from achieving-or usurping-those in power. Coomaraswamy (2003) referring to education in the Kandyan period says that children who did not attend a temple for learning, ended up learning from their 'fathers.' The absence of the 'mother' (and thereby female) from the formal teaching process is telling evidence of the gendered notions of education in ancient Lanka. At the same time, the location of the profession of teaching as a masculine prerogative- the privileged gender in ancient Lanka-might be an indication of the reputation with which this profession was upheld by the story creators/narrators/listeners.

\section{b) Teachers' Response to Failures in 'learning'}

The story tellers/creators/listeners treated students who failed to learn harshly - and their responses might be questionable for, if not shocking, to a modern-day practitioner. A teacher would send back a weak student to his parents-where terrible punishments awaited them like beheading or expulsion from the palace. In such instances, the 'teacher' or the act of 'teaching' was not questioned. Thus, in The Prince who Received the Turtle Shell, a teacher who assumes that "he could not teach" (Parker, 1912) a particular royal prince, complains to his father who takes the boy home. In the story The Story of the Cobra's Bite, a teacher complains to a king about his son: "Your Majesty, your son is unable to learn?" The king accepts the teacher's word without question. Learning was conceived by the story creators/tellers as the obligation of a learner-it 
is a biological inheritance, something that is in a child's 'nature' rather than something 'nurtured' through effective intervention. A teacher's role was that of a facilitator and a nurturer of a pre-existing skill in a learner. What Lanka's story creators/tellers might have wanted to tell their audiences was that 'learning' was closely connected to political power and those who failed to learn automatically relinquished this advantage. Therefore, 'learning' was a learner responsibility and not that of a teacher. It might be of interest here to note that Sri Lanka's modern Sinhala fiction follows the same representational mode when it comes to learning. In Martin Wickramasinghe's epic novel Gam Peraliya (Upheaval of the Village), Piyal outmaneuvers the feudal society of his village through his education; In Karulwala Gedara (The House in Darkness) by the same author, the main protagonist uses education as the pivotal pedal to achieve the same task, this time in Colombo. Similarly, in T.B. Illangaratne'a Amba Yahaluwa (Bosom Friends) the main character overcomes his poverty through education. All these novels focus on the learner's ability to learn-not necessarily the teachers' ability to teach.

\section{a) Exploiting students}

The tale Holman Pissa offers the rare incident of a teacher exploiting a female student. This teacher makes a marriage proposal to his student, a princess, who out of respect does not refuse him but stops going for lessons. The teacher takes revenge by giving a wrong prognosis of her astrological chart to her father, the king, thus influencing the king to expel her. Later, this princess extracts her revenge from this teacher. Exploitation of students by teachers occurs only once in the 266 tales, suggesting that such incidents were rare. This tale, while accepting the possibility of such events, offers a warning to those in teaching profession of the consequences of such action.

\section{Conclusions}

'Learning' and 'Teaching' as conceived by the story creators/tellers/listeners of ancient Lanka was part of the oppressive mechanism that sustained the power asymmetries of a social setting where caste and gender defined the sites of power. A person who combined these categories-high caste and male-was considered fit to learn-and 'fit to govern,' to quote a Shakespearean phrase. A 'teacher' was always a high caste male whose residence might have been the site of learning and was held in high esteem by those in power: More 
specifically, his word on the nature of the learning aptitude demonstrated by his student/s was accepted without question. Yet, the notions of 'teaching' and 'learning' might not have meant the same to those who heard these stories in ancient Lanka. For upper class/caste males, these terms carried meanings associated with a threat as well as empowerment: a threat because one could not let one's teacher down and afford to give away one's own social privileges and empowerment because 'learning' was one of the mileposts they passed on their way to power. For the females of the same class/caste the terms carried notions of restrictions and social knowledge: restrictions because females were warned off from both 'learning' and 'teaching'; social knowledge because a learned male was considered deserving of their love, respect and affection and a male who failed in 'learning' could be slighted and rejected by a female. As for the lower caste females and males, these stories might have created deep impressions of the power hierarchies that awaited them in the material sphere and also helped to re-establish their oppressed social positions. At the same time, these terms might not have carried meaning or significance for them because their lives and livelihood did not depend on formal access to learning. In that sense 'teaching' and 'learning' as conceived in the imaginary spheres of ancient Lanka were not acts only aimed at imparting/gaining knowledge for expanding of one's worldviews. Instead, they were loaded terms that preserved and disseminated subtle notions of power and prejudice. The phrase "your majesty, your son is unable to learn," just as much as it signifies that the teacher has nothing more to offer this student, also implies to the father and the king that he has no reliable successor to the throne. In other words, those words are not uttered for an individual, rather they are uttered for the entire 'nation' state-whatever the way people conceived their 'nation' to be as the story was created $/ \mathrm{read} /$ heard-reminding people that a royal male who cannot learn spells doom for the nation state.

\section{References}

Coomaraswamy, Ananda K. (2003). Mediaeval Sinhalese Art, Munshiram Manoharlal Publishers (Pvt) Ltd, New Delhi.

Davids, Rhys. (1987). Buddhist India, Motilal Banarsidass, New Delhi.

Dundes, Alan. (1980). Interpreting Folklore. Indiana University Press, Indiana.

Dunwala Mahanama, (20015). Prangi Rajjuruwo Saha Thawath Katha. 
Godagae, Colombo.

Gencarella Olbrys Stephen. "Gramsci, Good Sense, and Critical Folklore Studies." Journal of Folklore Research Vol. 47, No. 3 (September December 2010).

DOI: $10.2979 /$ jfolkrese.2010.47.3.221

Davy, John. (1983). An Account of the Interior of Ceylon and of its Inhabitants with Travels in that Island. Tissara Prakasakayo, Colombo.

Jayasuriya, J. E. (2018). The Buddhist Tradition in Education. In Dayantha Jayasuriya (Ed). Education in Sri Lanka. Past Present and the Future. Colombo: Nanila Publications.

Macherey, Pierre. (2016). A Theory of Literary Production. Routledge, London.

Man, John. (2011). Genghis Khan. Life, Death and Resurrection. Bantam Books, London.

Parker, H. (2010). Village Folk Tales of Ceylon Volume I. Tissara Prakasakayo, Colombo.

Parker, H. (2010). Village Folk Tales of Ceylon Volume II. Tissara Prakasakayo, Colombo.

Parker, H. (2010). Village Folk Tales of Ceylon Volume III. Tissara Prakasakayo, Colombo.

Parker, H. (1999). Ancient Ceylon. Asian Educational Service, New Delhi.

Ratnapala, N. (1991). Folklore of Sri Lanka. The State Printing Corporation, Colombo.

Ratnapala, N. (2000). Jana Katha:1. National Institute of Education, Colombo.

Roberts, Michael. (2003). Sinhala Consciousness in the Kandyan Period 1590s to1815. Vijitha Yapa Publications, Colombo.

Suraweera, A.V. (2008). Communication Modes in Sinhala Writing. A Retrospective Survey. Godage International Publishers (Pvt) Limited, Colombo.

Wickramagamage, Carmen. (2009). Where Have All the "Women" Gone? A Consideration of Gender and Literary Production in Sigiri Graffiti. The Sri Lanka Journal of Humanities, XXV. http://dlib.pdn.ac.Ik/handle/123456789/2754 